\title{
The Research of Islamic Sustainable Urbanization in the Issue of Urban Poor to Achieve Food Security in Malaysia Work
}

\author{
Syaidatana Siti Aishah Ab Aziz, Nurul Suhada Ismail
}

\begin{abstract}
The number of urban people in Malaysia has increased exponentially from 1970 which is from $27 \%$ to $71 \%$ in 2010. The increase in number of the urban population in such a short period of time has led to multiple problems including high cost of living, crime rate, social issues, and deterioration of the environment, unemployment and poverty. The issue of urban poverty in Malaysia has been regarded as a striking phenomenon caused by the urbanization process. Normally, urban poor residents run the risks of facing limited access to food and quality food to the point that their food security is affected. Thus, how to manage an Islamic city to overcome the problem of the urban poor? What are the values that we need to have in such management to fulfill food-related needs especially among urban poor? How are the values able to help guarantee the food security of urban poor in Malaysia? To answer all these issues, this paper work intends to identify the values in Islamic sustainable urbanization. Next, it analyses the values in managing food security for urban poor in Malaysia. This qualitative study using content analysis with secondary data collection integrates values of fairness, welfare and solidarity in fulfilling economic and social needs of urban poor.
\end{abstract}

Index Terms: Food security, Islamic sustainable urbanization, Malaysia, Urban poor.

\section{INTRODUCTION}

The exponential process of township and growth of urban residents has created various issues and problems in cities such as the increased rate of unemployment, social issues, low-cost housing and poverty. Urban poverty is an issue that has yet to be resolved. Data were obtained from the Economic Planning Unit (EPU) [1], showing that there is a decreasing trend in the urban poverty incidents. The poverty rate in cities has been noted to become lower, from $25.5 \%$ in 1970 to $0.3 \%$ in 2014 . The urban poor phenomenon is increasingly striking in Malaysia during this time because of the fast-paced development. The lower-income residents feel the blow the most because they have to struggle to allocate their income for various aspects of food, home, transportation, education and healthcare with high cost of living in the cities. In general, households in the cities need to prepare more financial allocation for daily uses such as water, food and rent if compared to people in the suburbs or rural areas [2]. Even poor households in developed countries spend more than 50 percent of their expenditure on food [3]. The risks of food scar town and imbalance have forced them to reduce other spending to fulfil their basic food needs [4].

Revised Manuscript Received on July 10, 2019.

Syaidatana Siti Aishah Ab Aziz, Centre for Islamic Development Management Studies (ISDEV), Universiti Sains Malaysia 11800 Penang, Malaysia.

Nurul Suhada Ismail, Centre for Islamic Development Management Studies (ISDEV), Universiti Sains Malaysia 11800 Penang, Malaysia.
One of the root causes might be due to the subsidy coordination and government policy that have an imbalanced effect on the society, especially the urban poor [5]. This indirectly causes food needs to become more and more affected as food access and quality food provision as well as food security for urban people, are limited. Basically, food security contains four dimensions including preparing food physically, accessing food economically and physically, using food and the stabilization of the three dimensions throughout [6]. Following this, the first section of this paper will identify values in Islamic sustainable urbanization. Then in the second part, the values will be analyses in managing food security for urban poor in Malaysia. What follows next will be the conclusion and discussion.

\section{METHODOLOGY}

This paper work is based on the qualitative study using the secondary data. Data collection refers to Quranic and hadith sources together with some written materials on Islamic sustainable urbanization to identify the values in Islamic sustainable urbanization. Then, this data is used for analysis to achieve food security among urban poor in Malaysia through content analysis.

\section{The Islamic Sustainable Urbanization Approach}

The discussion in this section focuses on identifying values in Islamic sustainable urbanization. First and foremost, the definition of Islamic sustainable urbanization is raised based on the opinion of the writer with regard to sustainable township and Islamic township. The concept of Islamic sustainable urbanization has yet to be defined and this is why there is no specific definition to interpret this keyword. Thus, the definition of sustainable urbanization has to be explored first and foremost. Sustainable township or town, according to the United Nations Centre for Human Settlement (HABITAT) in Sustainable Cities Program is the town or town that is able to maintain its achievement in the social, economic and physical developments. The meaning of sustainable cities according to [7], is a town that gives a better life quality to its residents with minimal use of natural resources [8].

More specifically, sustainable cities is also a cities that can fulfil current needs without having to affect the needs of the future generation to carry out the same thing. A

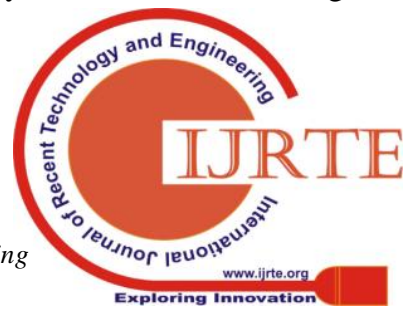




\section{THE RESEARCH OF ISLAMIC SUSTAINABLE URBANIZATION IN THE ISSUE OF URBAN POOR TO ACHIEVE FOOD SECURITY IN MALAYSIA WORK}

sustainable city provides relatively better quality of life. Some of the important components in sustainable cities include the integrity of the environment, life quality, economic security and democratic participation [9]. In [10] adds to the assertion that developing sustainability in the context of a town must fulfill certain requirements such as equity, social justice or fairness and human basic rights, human basic needs, social and ethnic, the awareness of the environment and integrity. According to [11], sustainable town is defined as the development of a sustainable cities that refers to the development of an ongoing social wellbeing. Part of the effort in the town's good wellbeing can be seen from the urban planning in terms of the physical, social and culture. Therefore, the habitation concept in town sustainability in the context of sustainable development indicates that the people are always happy, busy with various economy, social and physical, safe, interesting and healthy [12]. Nonetheless, these definitions of sustainable cities give more focus on sustainable introduced by the West without connecting any aspect of religion. The aspect of religion is important in managing and implementing any decisions or actions done by Muslims.

Therefore, the definition of Islamic cities is also raised in creating a wholesome definition of Islamic sustainable urbanization. The word 'town', according to Ibn Manzur is Medina that comes from the word madain. Madinah means the town built on the original birthplace of a civilization and the word is rephrased to Madinah al-Rasul. Other than that, in [13] adds to the assertion that an Islamic cities is a cities that leans on Islamic elements and values. Its residents' morality lies in succumbing to Allah SWT and the laws of the township are based on the al-Qur'an. Next, the moral of the residents is modelled on the Sunnah of the Prophet Rasulullah SAW. A modern Islamic cities places focus on Islamic understanding and philosophy as the main guidance. In this matter, Islamic towns reflect the religious ideas that represent Islam in all aspects. Islam as the space and communication for the cultural climate that influences the urban landscape, physical appearance, population structure also the relationship between one resident and another and their surrounding areas [14]. In this vein, in [15] explains that in an Islamic city, the residents have to understand the values instilled or the faith they hold on to. It is clear then that Islamic cities is a cities that has its own soul [16].

Based on the definitions of sustainable cities and Islamic cities explained earlier, it can be concluded that an Islamic sustainable township is a sustainable Islamic town, characterized by Islam and administered in an Islamic way. Islamic sustainable township also emphasizes on a comprehensive balance in the aspects of the environment, economy, sociopolitics and spirituality. The balance in all these aspects must be in tandem and at par with town development done, so that it can cater for the needs of the society today and for the future. Based on the Islamic sustainable township, it is found that there are three values that need to be considered in fulfilling the needs of the town residents that not only focusing on elite and middle classes only. The low-class people like urban poor should also be considered by both the government and the public. The following discussion should further be on values extracted from Islamic sustainable urbanization. The values are those

of fairness, welfare and solidarity. All these values are seen in terms of the economy and social of the urban poor themselves in ensuring that food security is not an issue.

\section{Fairness}

In managing the cities, the value of fairness in the economic and social systems needs to be emphasized. In its economic orientation, Islam has paid attention to the urban economic capability to prepare the people's economic needs. The main objective of the town economic planning would be to increase the income and increase the life quality of the people. Other than that, occupations and easy access to occupations and income must be focused on all citizens [17]. Therefore, fairness for all must be in tandem with the declaration of human basic rights whereby everyone has the right to obtain sufficient life status for the health and welfare of himself and his family including food, clothing, housing and so on. They have the right to get protection in cases of incapability, sickness or other depravity of life which are beyond control [18].

According to Quraish Shihab, the principle of balance demands humans to live in balance, in compatibility and in tune with himself or herself, their community, even with their surroundings. The purpose of this principle is to prevent all forms of monopoly and center of economy towards an individual or any particular group [19]. Allah SWT decrees a verse, meaning:

\section{"And what Allah restored property) to His Messenger from the people of the towns-it is for Allah and for the Messenger and for (his) near relatives and orphans and the (stranded) \\ traveller-so that it will not be a perpetual distribution \\ among the rich from among you. And whatever the \\ Messenger has given you-take; and what he has forbidden you-refrain from. And fear Allah; indeed, Allah is severe in penalty." (al-Hasyr, 59:7)}

This verse explains that the asset of wealth does not only circulate around millionaires and limited around the poor. Every position of the economy given to the rich opposes the Islamic economic theory other than being in contrast to the development regulation goals as a whole [20]. Thus, alQur'an condemns those who are fortunate and those in power, but who do not demonstrate any empathy towards the weak, like orphans, widows, the impoverished and the homeless [21]. Based on the history of the Islamic cities before the century, Mecca had been a well-developed city, bustling with business activities. Although Mecca was a dry land and agricultural activities were nearly impossible there, with the mercy of Allah SWT, its people were protected from starvation and fear. During the era of the Rasulullah SAW and Abu Bakar, the national treasury resources were obtained through zakat collection, donations, jizyah, ghanimah and al-fay. All of the national income was spent fully on the people in need and who had the rights to receive it [13]. According to [22], social development should be one that complies with the fairness principles. His opinion about fairness is that it encompasses and includes social justice 
and social distribution. When distributing wealth, it is fair to prepare the same opportunity to all citizens. In [22] determines on the public spending on human's wellbeing by looking at the role of zakat, waqaf and donations as additions to the spending from the treasury. This means giving power to the poor and the weak economically through a direct and an indirect assistance [23]. The value of fairness in giving donations instilled through the granting of zakat can help reduce one's sufferings, hardship and inadequacy for those less fortunate especially concerning food [24].

With that, the distribution system in the Islamic economy must be based on the basic principles of Islamic economy, among which are individual freedom, social assurance, the prohibition of accumulating wealth and assets and fair distribution of wealth [25]. Fairness is also needed in the distribution of wealth towards the society. Social justice aims to reduce inequality by eliminating the poverty gap [26]. In fulfilling the economic needs of the urban residents in particular, the value of welfare is significant to help the people in need and cater for their food needs.

\section{DISCUSSION \& RESULTS}

\section{Welfare}

Other than that, in urban development management, the welfare value has to be instilled in the society. Islam promotes social justice. Human beings helping one another is a common and natural instinct among individuals. One cannot free himself from being dependent on other people. In Islam, this mutual help principle is called ta'awun which is a mutual responsibility between Muslims especially and among humans, generally [27]. Allah SWT decrees a verse, meaning:

Righteousness is not that you turn your faces toward the east or the west, but (true) righteousness is (in) one who believes in Allah, the Last Day, the angels, the Book, and the prophets and gives wealth, in spite of love for it, to relatives, orphans, the needy, the traveler, those who ask (for help), and for freeing slaves; (and who) establishes prayer and gives Zakah; (those who) fulfil their promise when they promise; and (those who) are patient in poverty and hardship and during battle. Those are the ones who have been true, and it is those whose are the righteous (alBaqarah, 2:178)

The verse above explains that Allah SWT orders that we priorities others although we need something ourselves such as infaq or donating the food that we like. Allah SWT orders that we treat orphans well because they do not have anyone who can support them financially, they are left abandoned by their father by death when they are still weak and small and who have no capability yet to find their own income. Other than that, donations must also be spared for the poor who do not have food, clothing and accommodation needs fulfilled. Next, Ibnu Sabil who was a traveler and who had run out of basic supplies must be assisted so he could get back to his home. Assistance like zakat and donations must be given to those asking for it. Allah SWT also orders that slaves should be made free- those who made the agreement to redeem themselves and who did not have the money to do. This verse shows that there is an element of patience in times of hardship and suffering. Patience is the virtue of piety. They donate the assets that they love, perform prayers, issue zakat and seal a deal. They are able to carry out their duties and play the role that has been decided by Allah SWT persistently, resiliently, calmly and moderately [20].

Islam promotes the concept of fairness on Muslims. It does not discriminate the rich from the poor or those with ranks and positions from common, ordinary men. In Islam, all humans are the same and share the same status. The much admitted difference would be related to one's individual faith or taqwa. Al-Qur'an has conditioned that all humans come from the same origin which is Adam a.s. [28]. According to [29], one is capable of doing two things. The first is an individual spiritual relationship that is vertically good. The second one is the social relationship that is horizontally good. This shows that one is able to perform an individual spiritual relationship and a horizontal social relationship. For people who are able to do both of them well, they are not only adored by the people around them but they are also loved and improved in status by Allah SWT.

One of the criteria of the Madani society that exists in Medina is the balance between social rights and social obligations. Every member of the society has a balanced right and obligation to create peace, harmony and solidarity. The concepts of zakat, infaq, donations and hibah for Muslims also Jizyah and Kharaj for non-Muslims, create a fair balance to the problem. Such a balance would be imposed on all aspects of life, to the point that there is no group that is treated more special than other social groups [30]. During the ruling of Umar, social welfare is very much prioritized. Social assistance is given to those categorized as the poor and those incapable of working. Khalifah Umar alKhattab did this by determining a minimum life status that can become reference in created the poverty line. During that time, other than receiving money, the poor will accept about $50 \mathrm{~kg}$ of flour every month. To prevent dependency and acts of begging, those entitled to receive government's social assistance will be asked to perform community work [31]. Ibn Hazm contended that rich people have the responsibility to fulfil the needs of the poor. State rulers have to force them to prepare their essentials, clothing and housing that ensure protection and privacy [32]. Here, solidarity among the urban residents is crucial to ensure that food gets to be distributed sufficiently to those in need.

\section{Solidarity}

Through the solidarity value in the Islamic sustainable urbanization, it can be instilled through the neighborhood or bonding of the people who really care and who are concerned about each other. According to [33], manhaj rabbani can be seen through the commands of Allah SWT to humans to preserve their relationship through the implementation of all orders and to leave behind all that $\mathrm{He}$ forbids, and at the same time Allah SWT orders humans to preserve their relationship with humans. Certain morality and manners have been outlined in the al-Qur'an and 


\section{THE RESEARCH OF ISLAMIC SUSTAINABLE URBANIZATION IN THE ISSUE OF URBAN POOR TO ACHIEVE FOOD SECURITY IN MALAYSIA WORK}

Sunnah to take care of their relation between a human and another in every social level starting from the relationship between a husband and a wife, parents and children, neighbors, the relationship in the society and the relationship between the people and their rulers. Relationships in social institutions like this carry their own morality, manner, rights, orders and prohibitions that have been outlined by Allah SWT and His Prophet [34]. The value of solidarity can be widened through the participation of the public and social interactions especially in towns- this ensures a peaceful surrounding and environment and life comfort. AlQur'an mentions about the indicators of wellbeing in surah Quraisy. Allah SWT decrees:

\section{"Let them worship the Lord of this House. Who has fed them, (saving them) from hunger and made them safe, (saving them) from fear. (Quraysh, 106:3-4)}

This verse explains that based on the land of the state, the people should have been consistently threatened by starvation, but Allah SWT rescued them by providing them food supplies. They should have always been afraid, judging by their weakness and based on their surroundings, but Allah SWT makes them feel calm and peaceful [35]. It is for them to worship Allah SWT and not finding other entities in place of Him [36]. There is a hadith that encourages one to share their resources with the neighbors to avoid wasting away or spending extravagantly [37]. Abdullah bin Zubayr narrated that he once heard the Prophet SAW dictate:

Ibn 'Abbas told Ibn a-Zubayr, "I heard the Prophet, may Allah bless him and grant him peaced, say, "A man is not a believer who fills his stomach while his neighbour is hungry." (Sahih al-Albani: 12)

Muhammad SAW was really concerned about social issues such as poverty, converts, the wellbeing of Muslims and facing the jahiliyah. He exerted some efforts in improving and observing his followers' life needs. The forms of social wellbeing during the time of the Prophet in principle, are similar to the social wellbeing we are enjoying today, although the era, situations and circumstances remain different. During his time, social issues managed to be resolved directly by him. Muhammad SAW also practiced donating to his people in the month of Ramadhan. Muhammad SAW was really particular about Ramadhan, because it is a special month compared to the others [38]. Infaq given, indirectly helped the people in need especially in getting sufficient food. Thus, the Islamic sustainable urbanization approach based on the values of fairness, welfare and solidarity is evident in the achievement of food security in Malaysia.

The Achievement of Food Security in Malaysia among the Urban Poor in Malaysia Based on the Islamic Sustainable Urbanization Approach

Next, in this section, we will discuss and analyse the values of Islamic sustainable urbanization in managing food security especially towards the urban poor in Malaysia. As found in the first section, the three main values that have become fundamental in the Islamic sustainable urbanization and they are fairness, welfare and solidarity in the context of fulfilling the economy and social aspects of the society. This network of values forms an approach that leads towards achieving food security for the urban poor in Malaysia.

Based on the definition of food security, the components involved cover the elements of availability, accessibility, food use and stability to the population in a continuous way. The achievement of food security is very important to the residents because food is human's basic right as mentioned in the hadith of Rasulullah SAW which means:

Uthman ibn Affan reported: The Prophet, peace and blessings be upon him, said, "There is no right for the son of Adam except in these things: a house in which he lives, a garment to cover his nakedness, a piece of bread and water." (Sunan al-Tirmidhī: 2341)

Due to this, the emphasis is laid on the ability to access quality food. Currently, the urban poor are exposed to some limitations in terms of accessibility and food stability. Therefore, through the values of fairness, welfare and solidarity in Islamic sustainable township the food security can be achieved. The first is through the role of the rulers in addressing this because of the power vested in them. The responsibilities of the rules are in preparing sufficient amount of food, food that is halal and safe for the people [39]. This proves that it is the collective responsibility of the rulers as part of the society which, at the same time, gives life to the entire town.

The lack of affordability to buy from the market has become a problem to the urban poor that it influences food accessibility [40]. Thus, it has become the priority to make sure on price stability to help urban poor who are affected by the cost of living in town. In general, the rise in the food price influences the household spending that it affects food security. When the food price increases, low-income households will have the tendency to allocate most of the spending on food [41]. This causes the urban poor to priorities their income for food compared to other equally pressing needs.

Thus, administrators as the authority have to formulate a policy or strategy with regard to price control for basic food needs other than giving incentives and subsidy to the food materials. Automatically, the residents will have a high purchasing power towards food in line with the income rate of the urban poor. Even the welfare of the people can be assured when there is assurance of price stability by the administrators. The sustainability of food accessibility for the urban people is also stronger with the intervention of the rulers following the values of fairness in sustainable Islamic development based on the economy that stresses on the capability of the urban economy to provide for the needs of its residents.

The values of welfare, fairness and solidarity in Islamic sustainable urbanization are materialized with applications based on Islamic economy to achieve food security among urban poorites. The 
instruments of zakat, waqf, infaq and sadaqah are methods adopted to reduce the rate of poverty of the people also increase residents' living status [42],

The implementation of the instrument assures the fairness in the food distribution because this activity is a good practice that must be implemented or done voluntarily [44]. In reference to the Islamic sustainable township, all these values are extracted through the implementation of the Islamic economic instrument concentrating on the balance between the economy and the society.

In the context of food security, the wealth redistribution can be generated through zakat as the wealth is not accumulated in one group, but rather circulates to the groups in need. The implementation of zakat in every state, as it is in Malaysia has successfully shown that the need for basic food needs is met and at the same time their food security is guaranteed. The assistance given is in the form of physical food and financial assistance monthly or occasionally [45]. Although it is not sustainable for the recipients, this effort can help urban poor to achieve food security. The poor in the urban areas can still manage financially for example, to buy food. Additionally, residents who get food assistance will automatically gain access for quality food.

Zakat is the right of the poor from those who are rich [46] and at the same time, it displays a bond of solidarity among Muslims. The welfare of the people living in cities can be preserved and at the same time the rights of Allah SWT are fulfilled. Even the food security network in urban poor can be realized through campaigns of donations and infaq in the efforts to inculcate the values of welfare and solidarity. The suggestion for infaq is as narrated in surah al-Munafiqun verse 10 .

"And spend (in the way of Allah) from what we have provided you before death approaches one of you and he says, "My Lord, if only You would delay me for a brief term so I would give charity and be among the righteous. " (alMunafiqun, 63:10).

Such a contribution can be gathered in the food collection hall as the medium. The period of time needed to distribute the infaq is not only confined to Ramadhan but the entire time. It can open up opportunities to the society to help each other and share with those in need in the town. The effort to achieve food security must be carried out by all parties including the ruler, the community, business companies, non-government bodies and also individuals especially to help the urban poor.

For time being, for instance, concentrated food assistance has been established such as the Food Bank, targeting at urban poor such as homeless people, children and the households in need. For example, under the program Food Aid Foundation which collects food materials from the manufacturers, companies, wholesalers or individuals who wish to contribute food to charity homes, voluntary organizations, refugees, poor families and street kitchen programs. Through such programs, it can ensure that risked center by making the mosque, the musolla, the residential

people, who are also in poverty gain accessibility and food quality that can gradually strengthen food security for the urban poor community.

In specific, for the neighbourhood and the local community, the members of the society must be educated with the attitude of concern towards members of the society and produce the need to help and share with one another. Every individual has the responsibility to know about the others' conditions by helping to deal with the issue of food security. This action has to come from an individual to the community and the country [44]. For this reason, the urban society in the Islamic sustainable urbanization needs to achieve stability between their rights and social obligations through the values of fairness, welfare and solidarity to achieve food security for all residents. The Muslim solidarity values are built by providing enough food for other people because of the need to preserve human lives as depicted in the Quran:

"The believers are but brothers, so make settlement between
your brothers. And fear Allah that you may receive mercy." (al-Hujurat, 49:10)

\section{CONCLUSION}

Based on the discussion above, it can be concluded that the Islamic sustainable urbanization approach stressing upon the values of fairness, welfare and solidarity can be seen to be able to achieve food security for the urban poor. This group of people who face the issue of food depravity involving the lack of food and poor food quality is really in need of assistance. Thus, responsible parties especially rulers and the concerned local community need to play their role in helping the poor in the cities. Good moral values like fairness, welfare and solidarity need to be practiced ensuring continuing food security to the poor people in the cities.

\section{REFERENCES}

1. Economic Planning Unit (EPU), Incidence of poverty by ethnicity, strata and state, Malaysia, 1970-2012. Putrajaya: Prime Minister's Department, 2014.

2. E. Wratten, "Conceptualizing urban poverty," Environment and Urbanization, 7(1), 1995, pp. 11-39.

3. M. T. Ruel, J. Garrett, S. Yosef, and M. Olivier, "Urbanization, food security and nutrition," in Nutrition and Health in a Developing World, S. D. Pee, D. Taren, and M. W. Bloem, Eds. Cham: Humana Press, 2017, pp. 705 735.

4. I. Matuschke, "Rapid urbanization and food security: Using food density maps to identify future food security hotspots," International Association of Agricultural Economists Conference, 2009, pp. 1-15.

5. N. R. Zainal, G. Kaur, N. A. Ahmad, and J. M. Khalili, "Housing conditions and quality of life of the urban poor in Malaysia," Procedia-Social and Behavioral Sciences, 50, 2012, pp. 827-838.

6. Food and Agriculture Organization (FAO), Methods to Monitor the Human Right to Adequate Food. Rome: FAO, 2008

7. M. Roseland, "Dimensions of the eco-city," Cities, 14(4), 1997, pp. 197-202. 

ACHIEVE FOOD SECURITY IN MALAYSIA WORK

8. M. Lundqvist, Sustainable cities in theory and practice a comparative study of Curitiba and Portland. Bachelor thesis, Värmland: Karlstades University, 2007.

9. L. C. Wadhwa, "Global perspectives in suitable urban environments," in The Sustainable City II: Urban Regeneration and Sustainability. Advances in Architecture, C. A. Brebbia, J. F. Martin-Duque and L. C. Wadhwa, Eds. Southampton: WIT Press, 2002, pp. 3-11.

10. C. A. Brebbia, J. F. Martin-Duque, and L. C. Wadhwa, The Sustainable City II Urban Regeneration and Sustainability. Southampton: WIT Press, 2014.

11. D. Smith, "Third world cities: Sustainable urban development," Urban Studies, 33(4-5), 1996, pp. 673701.

12. A. H. H. Shah, A. S. Hadi, S. Idrus, and A. F. Mohamed, "Kelestarian bandar sebagai habitat manusia," SariInternational Journal of the Malay World and Civilisation, 28(2), 2010, pp. 175 - 194.

13. S. Idrus, Pembangunan mampan utamakan rakyat. Utusan online, 2009.

14. A. Z. A. Latiff, Perbandaran di Timur Tengah: Kesannya Terhadap Masyarakat Islam Abad I-III Hijrah. Kuala Lumpur: Dewan Bahasa dan Pustaka, 1997.

15. M. H. Sattari, A. Rajabi, and B. Jahangiri, A study on the concept of district. Available: http://docplayer.net/68437511-A-study-on-the-conceptof-district-or-neighborhood-in-islamic cities. html.

16. N. Samsudin. Perbandaran berteraskan Islam. Available: https://www.dwnbudaya.dbp.my/wordpress/?m=201202.

17. S. Saad, and M. M. Radzi, "Urus tadbir sebuah bandaraya Islam Malaysia: Kajian kes di Kota Bharu, Kelantan," Malaysian Journal of Society and Space, 5(3), 2009, pp. 8-25.

18. F. Shojaee, and M. Paeezeh, "Islamic city and urbanism, an obvious example of sustainable architecture and city," Science Journal, 36(6), 2015, pp. 231-237.

19. United Nations, Universal declaration of human rights. Available: https://www.un.org/en/universal-declarationhuman-rights/index.html.

20. Z. A. Majid, "Ekonomi dalam perspektif pp. 251-260.

21. S. Qutb, Tafsir Fi Zilal Qur'an: Di Bawah Bayangan AlQur'an, (Yusoff Zaky Yacob, Trans.). Kelantan: Pustaka Aman Press Sdn. Bhd, 2000.

22. W. A. G. Andayani, "Tafsir kesejahteraan sosial (Al'adlul ijtima'i/Sosial welfare) dan strategi mewujudkan kesejahteraan dalam al-Qur'an," in Interkoneksi Islam dan Kesejahteraan Sosial: Teori, Pendekatan dan Studi Kasus, Zainudin, A. Torrido, A. Maftuhin, A. Muflihati, M. I. Haq, Noorkamilah, Suisyanto, A. Jahidin, S. S. M. Nazili and M. U. Absor, Eds. Yogjakarta: Penerbit Samudera Biru, 2012.

23. I. Khaldun, The Muqaddimah. (Franz Rosenthal, Trans.). New York: Patheon Press, 1967.

24. M. T. S. H. Mohammad, "Principles of sustainable development in Ibn Khaldun's economic thought," Malaysian Journal of Real Estate, 5(1), 2010, pp. 1-18.

25. N. M. Aris, S. D. Adnan, and M. F. Nasir, "Sekuriti makanan menurut konsep filantropi Islam," Journal of Islamic Philanthropy and Social Finance, 1(2), 2017, pp. 42-57.

26. M. Holis, "Sistem distribusi dalam perspektif ekonomi Islam,” Jurnal Perbankan Syariah, 1(2), 2017, pp. 1-14.

27. R. Darskhan, J. Paybandi, and S. M. Hosein, "An analysis of Islamic-political economy impact on sustainable urban development (Case: City of Zanjan)," Journal of Urban Economics and Management, 6(21), 2018, pp. 15-31. Alquran,” AHKAM: Jurnal Ilmu Syariah, 16(2), 2016 ,

28. Hariyanto, "Prinsip keadilan dan musyawarah dalam hokum Islam serta implementasinya dalam negara hukum Indonesia,” Justicia Islamica: Jurnal Kajian Hukum dan Sosial, 11(1), 2014, pp. 43-66.

29. M. A. S. Yusuf, and A. Durrah, Pustaka Pengetahuan AlQuran. Indonesia: PT. Rehal Publika, 2007.

30. A. Rohman, "Stratifikasi sosial dalam al-Qur'an," Jurnal Sosiologi Islam, 3(1), 2013, pp. 17-32.

31. A. D. Umar, Masyarakat Madani. Jakarta: Gema Insani, 1999.

32. E. Suharto, Islam dan negara kesejahteraan. Available: http://www.policy.hu/suharto/Naskah\%20PDF/IslamNeg araKesejahteraan.pdf.

33. M. U. Chapra, Objectives of the Islamic Economic Order. Leicester: The Islamic Foundation, 1979.

34. A. A. al-Fauzan, Fikih Sosial: Tuntutan dan Etika Hidup Bermasyarakat. Jakarta: Qisthi Press, 2007.

35. Z. Hussin, S. Siraj, Z. H. A. Malik, M. R. Jamil, A. A. Sapar, and N. M. Noh, "Pembangunan akhlak dan moral ke arah masyarakat lestari," Al-Hikmah, 7(2), 2015, pp. $72-87$.

36. S. Qutb, Tafsir Fi Zilal Qur'an: Di Bawah Bayangan AlQur'an, (Yusoff Zaky Yacob, Trans.). Kelantan: Pustaka Aman Press Sdn. Bhd., 2000.

37. Ibn Katsir, Tafsir Ibn Katsir, (M. Abdul Ghoffar and Abu Ihsan al-Atsari, Trans.). Jakarta: Pustaka Imam AsySyafie'i, 2017.

38. A. H. Ansari, P. Jamal, and U. A. Oseni, "Sustainable development: Islamic dimension with special reference to conservation of the environment," Advances in Natural and Applied Sciences, 6(5), 2012, pp. 607-620.

39. Zainudin, "Kesejahteraan sosial dalam hadis," in Interkoneksi Islam dan Kesejahteraan Sosial: Teori, Pendekatan dan Studi Kasus, W. A. G. A. A. Maftuhin, A. Muflihati, M. I. Haq, Noorkamilah, Suisyanto, A. Jahidin, S. S. M. Nazili and M. U. Absor, Eds. Yogjakarta: Penerbit Samudera Biru, 2012.

40. N. A. Ishak, and P. F. Othman, "Food security in Malaysia from Islamic perspective," Jurnal Syariah, 13(2), 2005, pp. 1-5.

41. C. Tacoli, "Food (In) in security in rapidly urbanising, low income context," International Journal Research and Public Health, 14(12), 2017, pp. 1-8.

42. E. Millstone, and T. Lang, The Atlas of Food: Who Eats What, Where and Why. London: Eathscan Publications Ltd., 2008.

43. M. B. Yusoff, "Fiscal policy in an Islamic economy and the role of zakat," International Journal of Economics, Management and Accounting, 14(2), 2006, pp. 117-145.

44. I. E. Khuluqo, "The role of zakat in national economic development," International Journal of Business, Economics and Law, 9(5), 2016, pp. 214-223.

45. M. Haddad, "An Islamic perspective on food security management," Water Policy, 14(S1), 2012, pp. 121-135.

46. N. S. Ismail, and W. N. W. Hasan, "Zakat expenditure on food security for sustainable development," Persidangan Serantau Fiqh Harta dan Masyarakat Wasatiy, 2017, pp. 13-20.

47. N. Hossain, L. Brito, F. Jahan, A. Joshi, C. NyamuMusembi, B. Patnaik, M. Sambo, A. Shankland, P. ScottVilliers, D. Sinha, and D. Kalita, Them belly full (but we hungry): Food rights struggles in Bangladesh, India, Kenya and Mozambique. Synthesis report from DFID-ESRC Research Project, Food Riots and Food Rights, Brighton: Institute of Development Studies, 2014. 